Article

\title{
Impact of CSR-Relevant News on Stock Prices of Companies Listed in the Austrian Traded Index (ATX)
}

\author{
Manuela Ender ${ }^{1, *}$ and Finn Brinckmann ${ }^{2}$ \\ 1 Campus Urstein, Salzburg University of Applied Sciences, Urstein Süd 1, 5412 Puch/Salzburg, Austria \\ 2 Biogena Management Holding GmbH, Strubergasse 24, 5020 Salzburg, Austria \\ * Correspondence: manuela.ender@fh-salzburg.ac.at; Tel.: +43-50-2211-1126
}

Received: 7 February 2019; Accepted: 18 June 2019; Published: 28 June 2019

\begin{abstract}
This paper examines the short-term influence of CSR-relevant news on the enterprise value in the form of respective shareholder value, which is represented by the corresponding stock price. This effect is measured using an event study applied to companies in the "Austrian Traded Index" (ATX). Subsequently, the results of the study show that CSR-relevant news in the financial portal finanzen.net trigger statistically significant abnormal returns and average cumulated abnormal returns within a period of five days. Based on these research results, it is stated that CSR-relevant news has a significant impact on the shareholder value of a company represented by its stock price. The hypotheses defined on the basis of the previously conducted studies on this topic were only partially confirmed. In particular, the negative effects of negative CSR-relevant news are insufficiently shown. Based on these findings, it can be deduced that the effects of the news are reinforced by the CSR relevance, although media presence due to the publications is a factor to be explored.
\end{abstract}

Keywords: corporate social responsibility; CSR-relevant news; event study; Austrian Traded Index

JEL Classification: G14; G32; Q56

\section{Introduction}

People's activities are changing the environment. For example, the exponential growth of humanity has led to the exploitation of groundwater (Smith et al. 2010). Chemicals and plastics are either actively produced or by-products of another production process. They are integrated into the natural cycle and subsequently change it (Jones and Gomes 2014). Companies play a major role in the act of changing the environment because they trigger or intensify such effects through short-term motivated actions. The profit is maximized regardless of the long-term consequences (Smith et al. 2010).

At the same time, companies have the opportunity to reduce these impacts on the environment with comparatively minor changes. The integration of Corporate Social Responsibility (CSR) leads to a focus on measuring, improving and communicating a company's activities, metrics, and developments that protect planet Earth and its inhabitants from damage that can either only be reversed with increased (time-) effort or not at all (White 2009). Businesses are therefore increasingly aware of their responsibility for sustainable development. Thereby the relevance of CSR rises due to the adoption of this concept by organizations in different sectors (Barth and Wolff 2009; Babiak and Trendafilova 2011). This development will continue over the next years as the pressure on society and companies to change the existing system is increased by ongoing climate change (Borowy 2014).

CSR describes a company's contribution to sustainable development beyond the legal requirements (ISO 2010). CSR also means dealing responsibly with those involved in or affected by the value-added process (Vilain 2010). The concept of CSR focuses on the sustainable management of the company, where the concerns of the stakeholders are linked, natural resources are used sparingly and both the 
ecological and the social environment are protected (Jonker et al. 2011). CSR-relevant news describes published announcements associated with CSR (Oikonomou et al. 2018). In recent years, several papers have provided insights on how CSR-relevant news influences the firm value measured by the stock price. The focus of those studies is mainly on the USA (Cheung 2010; Godfrey et al. 2009; Griffin and Sun 2013; Hamilton 1995; Hannon and Milkovich 1996; Karpoff et al. 2005; Krüger 2015; Ramchander et al. 2012). There are only a few studies on the impact of CSR-relevant news on the stock price in Europe (Cellier and Chollet 2011) and there is not one for companies in Austria. Capelle-Blancard and Petit studied companies worldwide, but a company from Austria was not included (Capelle-Blancard and Petit 2017). However, Austria is an interesting country as the public discussion about CSR started comparatively late, in 2003 (Keinert-Kisin 2015). The reason could be that environmental protection and social standards have been high since the Second World War. As regulations are already relatively high in Austria it is interesting to analyze what the impact of CSR-relevant news on the firm value is. But there is a research gap in the existing literature. There is no discussion of the actual short-term impact on stock prices of Austrian-listed companies. This paper aims to close this research gap. Therefore, the research question is as follows: What short-term effects did CSR-relevant news have on the stock prices of companies listed in the Austrian Traded Index (ATX) within the last three years and how can these findings be used in practice?

The following two hypotheses are examined in a superordinate way:

Hypothesis $\mathbf{0}\left(\mathbf{H}_{\mathbf{0}}\right)$. CSR-relevant news does not influence the stock price movements of companies in the ATX.

Hypothesis $\mathbf{1}\left(\mathbf{H}_{\mathbf{1}}\right)$. CSR-relevant news influences the stock price movements of companies in the ATX.

The null hypothesis must be refuted in order to accept $\mathrm{H}_{1}$ and, therefore, to confirm a connection between CSR-relevant news and the stock price movements of companies in the ATX. This research is done by calculating the average abnormal return and the cumulated average abnormal return. The price data records are downloaded from finance.yahoo.at ${ }^{1}$ and the reports are filtered from the financial platform finanzen.net ${ }^{2}$ using a criteria catalog with a focus on CSR.

The remainder of this article is structured as follows: Section 2 gives a short literature review that shows the current state of research. Afterwards, Section 3 illustrates the methodology used by explaining the formulas applied in the calculations. Section 4 describes the sample and the data with a following presentation of the results. This section includes a robustness check. To complement this paper Section 5 discusses the outcomes in a critical way.

\section{Literature Review}

\subsection{CSR Impact on Firm Value}

In the literature, there is still a controversy on the question whether CSR activities have a positive or a negative impact on the market value of companies. The main argument why CSR activities reduce the value is that corporate actions in this area increase costs (Becchetti et al. 2012; Harjoto and Jo 2015). Additional rules narrow the scope of managerial decisions and limit the opportunities. On the other hand, many positive effects are stated in the literature. No wage benefits for employees enhance their productivity. Increasing the intrinsic motivation of the employees can reduce costs as they are more likely to accept lower remuneration (Dhaliwal et al. 2014). Further, CSR activities reduce conflicts with all kinds of stakeholders (Freeman 1984). Suitable CSR actions can improve the company's reputation and reduce the risk of being sued (Lee and Roh 2012; Schiff and Mittelbach-Hörmanseder 2018).

\footnotetext{
https://finance.yahoo.com/?guccounter=1.

https://www.finanzen.net.
} 


\subsection{Event Studies on CSR-Relevant News}

Given the assumption of efficient capital markets, the stock price of a listed company should promptly reflect the implication of an event. The methodology of an event study reveals the short-term impact of an occasion on the value of a firm (Fama 1991; McWilliams et al. 1999; Mitchell and Netter 1994; Kliger and Gurevich 2014).

The overview of the current state of research is provided by ten event studies in the field of stock reactions to news with CSR content. The hypotheses relevant to our empirical research are derived from the current state of research. McWilliams et al. (1999) compare various event studies from different sources. The comparison of the studies is based on the criteria used in this meta-study. The details of each study are listed in Tables 1-3. The day of the event has the denotation [0]. If the day before the event is examined, $[-1]$ is used as an abbreviation. One day after the event is indicated with [1] and so on. If the event window includes more than one day, the length of the time window is presented as the interval $\left[t_{1}, t_{2}\right]$, where $t_{1}$ denotes the start date and $t_{2}$ denotes the end date of the event window.

Table 1. Event studies in the category environment.

\begin{tabular}{|c|c|c|c|c|}
\hline Study & Time Window & Sample Size & $\begin{array}{l}\text { Year and } \\
\text { Geography }\end{array}$ & Research Findings \\
\hline Hamilton (1995) & $\begin{array}{c}{[-1]} \\
{[0]} \\
{[0,5]}\end{array}$ & 436 & $\begin{array}{l}1989 \\
\text { USA }\end{array}$ & negative abnormal return \\
\hline Karpoff et al. (2005) & {$[-1,0]$} & 487 & $\begin{array}{c}\text { 1980-2000 } \\
\text { USA }\end{array}$ & negative abnormal return \\
\hline Griffin and Sun (2013) & {$[-2,2]$} & 172 & $\begin{array}{l}\text { 2000-2010 } \\
\text { USA }\end{array}$ & positive abnormal return \\
\hline
\end{tabular}

Source: Own representation based on (McWilliams et al. 1999).

Table 2. Event studies in the category society.

\begin{tabular}{ccccc}
\hline Study & Time Window & Sample Size & $\begin{array}{c}\text { Year and } \\
\text { Geography }\end{array}$ & Research Findings \\
\hline $\begin{array}{c}\text { Hannon and Milkovich } \\
(1996)\end{array}$ & {$[-2,2]$} & 290 & $\begin{array}{c}1982-1989 \\
\text { USA }\end{array}$ & Positive abnormal return \\
\hline Godfrey et al. (2009) & {$[-1,0]$} & 187 & $\begin{array}{c}1993-2003 \\
\text { USA }\end{array}$ & Negative abnormal return \\
\hline Krüger (2015) & {$[-5,5]$} & 2116 & $\begin{array}{c}\text { 2001-2007 } \\
\text { USA }\end{array}$ & Negative abnormal return \\
\hline & Source: own representation based on (McWilliams et al. 1999).
\end{tabular}

Table 3. Event studies in the category governance.

\begin{tabular}{ccccc}
\hline Study & Time Window & Sample Size & $\begin{array}{c}\text { Year and } \\
\text { Geography }\end{array}$ & Research Findings \\
\hline $\begin{array}{c}\text { Arya and Zhang } \\
(2009)\end{array}$ & {$[-1,1]$} & 71 & $\begin{array}{c}1996-2005 \\
\text { South Africa }\end{array}$ & Positive abnormal return \\
\hline Cheung (2010) & {$[-5,5]$} & 177 & $\begin{array}{c}2002-2008 \\
\text { USA }\end{array}$ & $\begin{array}{c}\text { Positive and negative } \\
\text { abnormal return }\end{array}$ \\
\hline $\begin{array}{c}\text { Ramchander et al. } \\
(2012)\end{array}$ & {$[0,0]$} & 194 & $\begin{array}{c}1990-2007 \\
\text { USA }\end{array}$ & $\begin{array}{c}\text { Positive and negative } \\
\text { abnormal return }\end{array}$ \\
\hline $\begin{array}{c}\text { Cellier and Chollet } \\
\text { (2011) }\end{array}$ & {$[-1,3]$} & & $\begin{array}{c}\text { 2004-2009 } \\
\text { Europe }\end{array}$ & $\begin{array}{c}\text { Positive and negative } \\
\text { abnormal return }\end{array}$ \\
\hline
\end{tabular}

Source: Own representation based on (McWilliams et al. 1999). 
The theoretical model for a clear classification of the scientific studies provides the ESG Rating of MSCI ESG Research. ESG stands for environment, social and governance (MSCI ESG Research 2015). The category environment includes topics such as climate change, renewable energies, and sustainability. The second category, society, covers issues such as human capital, labor management, and social opportunities. As a third and final category, governance includes topics such as corporate governance and conduct in relation to business ethics (MSCI ESG Research 2015).

\subsection{Environment}

Hamilton (1995), Karpoff et al. (2005) and Griffin and Sun (2013) examined studies on pollution and violations of environmental regulations. The details of those studies are shown in Table 1.

Hamilton demonstrated that the publication of toxicological performance indicators by the US Environmental Protection Agency leads to a statistically significant negative abnormal return on the day of disclosure (Hamilton 1995).

Karpoff et al. reported a statistically significant loss of stock prices in the event of a violation of environmental laws (Karpoff et al. 2005). The amount of losses is of a similar magnitude to the legally imposed sanctions (Karpoff et al. 2005).

Griffin and Sun explored voluntary publications through the news portal CSRwire, a leading source of CSR information and events on CSR (Griffin and Sun 2013). As a result of this research, it was described that the publication of news with content about greenhouse gas emissions leads to a positive abnormal return for shareholders (Griffin and Sun 2013).

\subsection{Society}

Hannon and Milkovich (1996), Godfrey et al. (2009), and Krüger (2015) studied stock reactions due to news related to society and various stakeholders. The details of those studies are shown in Table 2.

Hannon and Milkovich examined that being named as one of the best companies for working women leads to a positive abnormal return (Hannon and Milkovich 1996).

Godfrey et al. testified in their study that a negative event results in a negative abnormal return (Godfrey et al. 2009). In addition, it has been confirmed that CSR has an insurance-like effect, as companies dealing with CSR suffer fewer losses of market capitalization compared to companies that do not engage in CSR (Godfrey et al. 2009).

Krüger concluded that negative events lead to strong negative abnormal returns and positive events also to negative abnormal returns but only in a weakened form (Krüger 2015). It has also been shown that news with an increased content of legal and economic information leads to stronger reactions of stock prices (Krüger 2015).

\subsection{Governance}

Arya and Zhang (2009), Cheung (2010), Ramchander et al. (2012), and Cellier and Chollet (2011) review how events related to the strategic implementation and subsequent management of CSR influence the stock prices of respective companies. The details of those studies are shown in Table 3.

Arya and Zhang examined that the publication of CSR initiatives during later phases of institutional reforms lead to a positive development of the stock prices (Arya and Zhang 2009).

Cheung found that inclusion in the Dow Jones Sustainability World Index, a stock index with a composition according to economic, environmental, and social criteria, leads to positive and exclusion to negative abnormal returns (Cheung 2010).

Ramchander et al. investigated the inclusion and exclusion in the Domini Social 400 Index, a social index of 400 US-based companies with an exceptional ESG rating (Ramchander et al. 2012; MSCI Inc. 2018). The result of this study is a positive reaction of the stock price of the announcing company and a negative response to stock prices of competing companies. Removal from the index leads to the opposite reaction (Ramchander et al. 2012). 
Cellier and Chollet received significant positive returns two days before and after the release of CSR ratings for European companies (Cellier and Chollet 2011). Additionally, announcements including human rights have a positive effect, announcements including environmental and human resources context have a negative impact on abnormal returns. The topic of contribution to society shows an abnormal return in both directions (Cellier and Chollet 2011).

\subsection{Hypotheses}

Based on the ten empirical studies presented before on stock reactions to CSR-relevant events, the hypotheses presented in Table 4 can be derived. The hypotheses $\mathrm{H}_{2}, \mathrm{H}_{6}$, and $\mathrm{H}_{10}$ state that the publication of positive CSR-relevant news leads to significant positive average abnormal returns. According to $\mathrm{H}_{3}, \mathrm{H}_{7}$, and $\mathrm{H}_{11}$ announcements with a positive tendency lead to significant positive cumulated average abnormal returns in the reviewed time window. The hypotheses $\mathrm{H}_{4}, \mathrm{H}_{8}$, and $\mathrm{H}_{12}$ state that the publication of negative CSR-relevant news leads to significant negative abnormal returns. $\mathrm{H}_{5}, \mathrm{H}_{9}$, and $\mathrm{H}_{13}$ connect the announcements with a negative tendency to significant negative cumulated average abnormal returns. The respective null hypotheses indicate that the publication of CSR-relevant news shows no significant or significant contrary results. The hypotheses do not distinguish between the three subcategories environment, society, and governance but differences in the results will be examined.

Table 4. Hypotheses derived from the literature review.

\begin{tabular}{cll}
\hline Tendency of Announcements & \multicolumn{2}{c}{ Hypotheses Derived } \\
\hline \multirow{3}{*}{ positive } & $\mathrm{H}_{2}, \mathrm{H}_{6}, \mathrm{H}_{10}:$ & AAR $>0$ \\
& $\mathrm{H}_{0}:$ & AAR $\leq 0$ \\
& $\mathrm{H}_{3}, \mathrm{H}_{7}, \mathrm{H}_{11}:$ & CAAR $>0$ \\
& $\mathrm{H}_{0}:$ & CAAR $\leq 0$ \\
\hline \multirow{3}{*}{ negative } & $\mathrm{H}_{4}, \mathrm{H}_{8}, \mathrm{H}_{12}:$ & $\mathrm{AAR}<0$ \\
& $\mathrm{H}_{0}: \mathrm{H}_{5}:$ & AAR $\geq 0$ \\
& $\mathrm{H}_{5}, \mathrm{H}_{9}, \mathrm{H}_{13}:$ & $\mathrm{CAAR}<0$ \\
& $\mathrm{H}_{0}:$ & CAAR $\geq 0$ \\
\hline
\end{tabular}

Source: Own representation.

\section{Methodology}

In the entire process of empirical research, objectivity is ensured as all stock prices are assessed according to the same pattern. Their reliability is ensured by an optimal balanced selection of the sample. In order to achieve validity, the evaluation scheme is directly aligned with the research question (Schnell et al. 2013).

Execution and evaluation follow Bowman's phase model of event studies. In total, five steps are performed, which are shown in Table 5 (Bowman 1983). After selecting the events to be explored in step one and establishing the hypotheses in step two, the abnormal returns are calculated in step three and cumulated in step four. The analysis of the research results is carried out as step five (Bowman 1983).

Table 5. Phase model for the systemic execution of an event study.

\begin{tabular}{cl}
\hline Step & Content \\
\hline 1 & Select event \\
2 & Establish hypotheses \\
3 & Calculate abnormal returns \\
4 & Calculate the cumulated abnormal returns \\
5 & Analyze the results \\
\hline
\end{tabular}

Source: Own representation based on (Bowman 1983). 
The time window investigated ranges from two days before the event indicated by [-2] to two days thereafter indicated by [2]. The time window of the event study and its descriptions are shown in Figure 1.

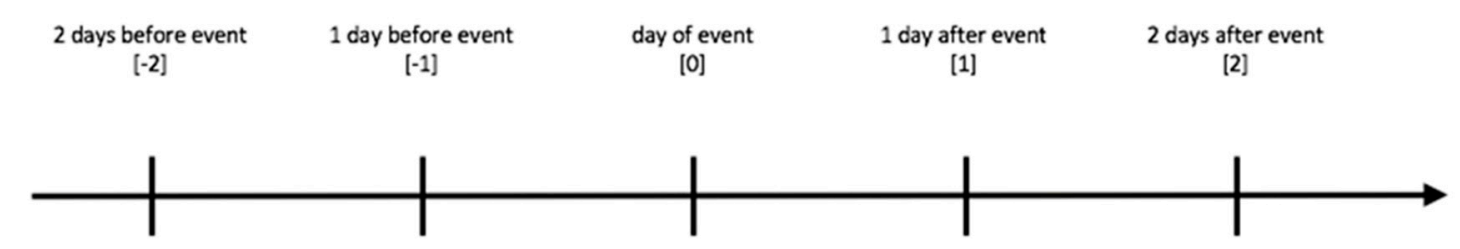

Figure 1. Time window of the event study. Source: own representation based on (McWilliams et al. 1999).

The qualitative data is evaluated using the approach of Mayring (2016). The methodology is chosen according to previous empirical studies in order to allow a comparison of results.

The following four key figures are calculated within the time window of 5 days $[-2,2]$ set around the moment of the announcement on finanzen.net (Kliger and Gurevich 2014):

- $\quad$ Abnormal return $A R$

- Cumulated abnormal return $C A R$

- Average abnormal return $A A R$

- Cumulated average abnormal return $C A A R$

The abnormal return AR of a stock $i$ at a certain point of time $t$ is calculated as the difference between the observed return $R$ and the expected return $K$ (Kliger and Gurevich 2014):

$$
A R_{i t}=R_{i t}-K_{i t}
$$

The expected return $K$ is calculated using the market model, which compares the return of a stock with a reference market. This role is played by the ATX, which is a price index developed by the Vienna Stock Exchange and that is representing the price movements of the 20 largest Austrian listed companies (Wiener Börse 2019a) The expected return of stock $i$ is the intersection $\alpha_{i}$ of the regression line plus the product of the slope of the regression line $\beta_{i}$ with the observed return $R$ of the reference market $m$ at time $t$ (Kliger and Gurevich 2014):

$$
A R_{i t}=R_{i t}-\left(\propto_{i}+\beta_{i} \times R_{m t}\right)
$$

The expected return $K$ is based on the observed returns of the 252 trading days before the time window examined. Thus, the observed returns from the last calendar year are included in the calculation (Morris 2014). The $t$-test is used to calculate the significance of the results. For this, the $t$-value of the previous outcome is determined by dividing the abnormal return by the standard deviation $\sigma$ of the values of the regression. Subsequently, the significance of the value is identified using the $t$-table with a notice that this test is two-tailed. Therefore, the value does not have to be divided by two (Kothari and Warner 2008):

$$
t-\text { value }_{A R}=\frac{A R_{i t}}{\sigma}
$$

Furthermore, the average abnormal return $A A R$ is calculated. For this purpose, the total abnormal returns are summed up on a uniform day $t$ of the time window and then divided by the quantity of the sample size N (Kliger and Gurevich 2014):

$$
A A R=\frac{1}{N} \sum_{i=1}^{N} A R_{i t} .
$$


This result is also checked for significance using the $t$-test. The root of the number of observed events is multiplied by the result of the average abnormal return $A A R$ divided by its standard deviation $\sigma_{A A R}$ (Kothari and Warner 2008):

$$
t-\text { value }_{A A R}=\sqrt{N}-\frac{A A R}{\sigma_{A A R}} .
$$

Subsequently, the cumulated abnormal returns $C A R$ are calculated, which is the sum of the five individual abnormal returns $A R$ of the respective time window (Godfrey et al. 2009):

$$
C A R\left(t_{-2}, t_{2}\right)=\sum_{t=t_{-2}}^{t_{2}} A R_{i t} .
$$

As stated earlier, the period examined ranges from two days before the event $t_{-2}$ until two days afterward $t_{2}$. The significance of the cumulated abnormal return CAR was determined using the $t$-test. For this purpose, the value of the cumulated abnormal return $C A R$ was divided by the result obtained by multiplying the root of the variance of the cumulated abnormal return with the length of the examined time window L (Kothari and Warner 2008):

$$
t-\text { value }_{C A R}=\frac{C A R\left(t_{-2}, t_{2}\right)}{\sqrt{L \times \sigma_{C A R}^{2}}}
$$

The last measure is the cumulated average abnormal return $C A A R$. This outcome is calculated as the sum of all cumulated abnormal returns of an examined category divided by their number (Kliger and Gurevich 2014):

$$
C A A R=\frac{1}{N} \sum_{i=1}^{N} C A R\left(t_{-2}, t_{2}\right)
$$

The last $t$-value is calculated by dividing the result of the cumulated average abnormal return $C A A R$ by its standard deviation $\sigma_{C A A R}$. This value is multiplied by the root of the sample number that gives the $t$-value (Kothari and Warner 2008):

$$
t-\text { value }_{C A A R}=\sqrt{N} \times \frac{C A A R}{\sigma_{C A A R}} .
$$

\section{Empirical Analysis}

\subsection{Sample and Data}

Since different markets respond unequally to information, the empirical research is limited to the geographic area of the ATX in order to correct the effects of market differences and obtain results with an increased informative value (Chan et al. 2000). For the sample of the event study, all announcements on the platform finanzen.net of companies listed on the ATX were examined within a three-year period between 1 September 2015 and 31 August 2018. The platform finanzen.net was chosen because the quality, completeness, and overview of the respective announcements on individual companies are leading for the German-speaking countries compared to other competing providers.

The relevance of CSR was examined and filtered using a catalog of criteria based on the ESG rating. The criteria for categorization are presented in Table 6 and serve the purpose of achieving the best objectivity possible and ensuring complete transparency of the overall research design (MSCI ESG Research 2015). For each event, its influence regarding the three categories in form of a specific act, behavior or error of the respective company was challenged. In addition, it categorizes whether the announcement is to be considered as positive or negative for the company. 
Table 6. Catalog of criteria for CSR-relevant news.

\begin{tabular}{|c|c|c|}
\hline Category & Topics & Key Terms \\
\hline \multirow{4}{*}{ Environment } & Climate change & $\begin{array}{l}\text { Sustainability report } \\
\text { Release of carbon }\end{array}$ \\
\hline & Natural resources & $\begin{array}{l}\text { Use of resources } \\
\text { Environmental destruction } \\
\text { Environmental protection }\end{array}$ \\
\hline & Environmental pollution & $\begin{array}{l}\text { Discharge of dangerous substances } \\
\text { Waste management }\end{array}$ \\
\hline & Ecological opportunities & $\begin{array}{l}\text { Driving the energy transition } \\
\text { Use of ecological opportunities } \\
\text { Building environmentally friendly infrastructure }\end{array}$ \\
\hline \multirow{4}{*}{ Society } & Human capital & $\begin{array}{l}\text { Innovation } \\
\text { Increase human capital }\end{array}$ \\
\hline & Labor force & $\begin{array}{l}\text { Appreciation of the employees } \\
\text { Establishing jobs }\end{array}$ \\
\hline & Product liability & Responsible investment \\
\hline & Social opportunities & $\begin{array}{l}\text { Charitable activities } \\
\text { Building infrastructure for society } \\
\text { Development of society }\end{array}$ \\
\hline \multirow[b]{2}{*}{ Governance } & Corporate management & $\begin{array}{l}\text { Rating based on ESG } \\
\text { Fulfillment of laws }\end{array}$ \\
\hline & Company's behavior & $\begin{array}{l}\text { Business ethics } \\
\text { Quality of relationships with stakeholders } \\
\text { Strengthening trust/peace } \\
\text { Charges/arguments/convictions } \\
\text { Corruption }\end{array}$ \\
\hline
\end{tabular}

Source: Own representation based on (MSCI ESG Research 2015).

The price data of the companies listed on ATX was imported from Yahoo Finance. The adjusted closing prices of the individual days were taken since this represents the last price of the stock on a day, adjusted to the price effects of stock splits and dividends in the considered period. Thus, a uniform and distortion-free calculation of abnormal returns is possible.

In the period relevant to the study, the ATX was not published on eleven days due to public holidays. These days are listed in Table A1 in the Appendix A. The sample was adjusted for these days. On 31 August 2018, the last day of the investigation, the ATX consisted of the companies listed below (Wiener Börse 2018).

- Andritz AG

- $\quad$ AT \& S Austria

- BAWAG Group AG

- CA Immobilien Anlagen AG

- Erste Group Bank AG

- FACC AG

- Immofinanz AG

- Lenzing AG

- Österreichische Post AG

- oMV AG

- PORR AG

- Raiffeisen Bank International AG 
- $\quad$ S IMMO AG

- Schoeller-Bleckmann Oilfield Equipment AG

- Telekom Austria AG

- Uniqa Insurance Group AG

- Verbund AG

- Vienna Insurance Group AG

- Voestalpine AG

- Wienerberger AG

Out of the 20 companies listed above, the following five do not have any CSR-relevant news on the platform over the period studied. Therefore, those five companies have no direct impact on the research results. Since they are all active in different industries, no conclusions can be drawn from this aspect.

- $\quad$ AT \& S Austria

- CA Immobilien Anlagen AG

- Erste Group Bank AG

- Schoeller-Bleckmann Oilfield Equipment AG

- Uniqa Insurance Group AG

Due to the $\mathrm{IPO}^{3}$ in October 2017, there is insufficient price data for BAWAG AG to calculate the expected return. Therefore, the sample does not include any CSR-relevant news from this company (Wiener Börse 2019b). Finally, the sample researched in the event study consists of 85 positive and 44 negative announcements (Table 7) with CSR context from a total of 14 companies.

Table 7. Sample size.

\begin{tabular}{ccc}
\hline Category & Positive & Negative \\
\hline Environment & 33 & 6 \\
Society & 44 & 6 \\
Governance & 8 & 32 \\
Total & 85 & 44 \\
\hline
\end{tabular}

Source: Own representation.

In order to gain an understanding of the results of the research and for the announcements contained in the sample, Table 8 gives an example for each category.

In total, 129 announcements remained after the filtering process based on the catalog of criteria and were therefore suitable for the event study. Of these 129 news, 118 defined the day of the message as $t_{0}$ of the investigated time window, while at eleven days $t_{0}$ was adjusted. Five notifications were published on days when the stock market was not opened for trading. Table A2 in the Appendix A provides an overview of these five reports. As a substitute for $t_{0}$ of these days, the next possible exchange trading day has been chosen. This way the reactions of the market triggered by the messages fall within the period of $t_{0}$. The remaining six reports were published after the announcement of the ATX was finished for that day. This is the case if the news was published on the original $t_{0}$ but between 17:31 and 23:59 of that day. These outliers were handled in a similar way as the publications on non-trading days. Instead of the original $t_{0}$ of the announcement, the next possible trading day has been selected, in order to exclude the reactions of the market at $t_{-1}$ and then include them at $t_{0}$. Table A3 in the Appendix A provides a clear overview of these six reports. Thus, the sample of the

3 Initial Public Offering. 
empirical research has been designed uniformly so that the reactions of the market are not included in $t_{-1}$, but in $t_{0}$. According to our research this is the most appropriate to deal with these anomalies. The dataset needed was imported into Microsoft Excel, where the formulas described were calculated in order to extract the results as the last step.

Table 8. Examples of CSR-relevant reports.

\begin{tabular}{cccl}
\hline Category & Tendency of Report & Company & Headline of Report \\
\hline \multirow{2}{*}{ Environment } & positive & Lenzing AG & 100 million Euro for sustainability * \\
\cline { 2 - 4 } Society & negative & OMV AG & $\begin{array}{l}\text { Greenpeace protests in front of OMV } \\
\text { headquarters against Arctic drilling * }\end{array}$ \\
\cline { 2 - 4 } & positive & Voestalpine AG & $\begin{array}{l}\text { Voestalpine supports hurricane } \\
\text { sufferers in Texas with 350,000 USD in } \\
\text { emergency funding * }\end{array}$ \\
\hline \multirow{2}{*}{ Governance } & pogative & Wienerberger AG & $\begin{array}{l}\text { End of April: Wienerberger closes } \\
\text { plant in Fürstenfeld * }\end{array}$ \\
\cline { 2 - 4 } & negative & Immofinanz AG & $\begin{array}{l}\text { Immofinanz wins 'Asset Management } \\
\text { Company of the Year' }\end{array}$ \\
\hline
\end{tabular}

Source: Own representation. * translated.

\subsection{Empirical Results}

This section is structured according to the categories of hypotheses. The components relate to the aspect's environment, society, and governance in line with the ESG rating and are additionally divided into positive and negative announcements.

\subsubsection{Environment-Positive}

A total of 33 announcements were assigned to this category. The average abnormal return $A A R$ was negative on the day before and on the day of the event. On the day before, the day after, and two days after the event, the average abnormal return was in the positive range. A significant positive return was recorded the day before the announcement and a highly significant one on the day after it (Table 9). The cumulated average abnormal return CAAR has a significant positive value, as shown in Table 9.

Table 9. Results of event studies.

\begin{tabular}{|c|c|c|c|c|}
\hline Category & Tendency of Reports & Hypotheses Established & AAR & CAAR \\
\hline \multirow[t]{2}{*}{ Environment } & positive & $\begin{array}{l}\mathrm{H}_{2}: \text { AAR }>0 \mathrm{c} \\
\mathrm{H}_{3}: \text { CAAR }>0 \mathrm{c}\end{array}$ & $\begin{array}{l}t_{-1} 0.0107^{*} \\
t_{1} 0.0113^{* * * *}\end{array}$ & $0.0107 * *$ \\
\hline & negative & $\begin{array}{l}\mathrm{H}_{4}: \text { AAR }<0 \\
\mathrm{H}_{5}: \text { CAAR }<0\end{array}$ & $t_{0} 0.0138^{* * *}$ & 0.0199 \\
\hline \multirow[t]{2}{*}{ Society } & positive & $\begin{array}{l}\mathrm{H}_{6}: \text { AAR }>0 \mathrm{c} \\
\mathrm{H}_{7}: \text { CAAR }>0 \mathrm{c}\end{array}$ & $\begin{array}{l}t_{-2} 0.0057 * * * \\
t_{1} 0.0062 * * *\end{array}$ & $0.0148^{* * *}$ \\
\hline & negative & $\begin{array}{l}\mathrm{H}_{8}: \text { AAR }<0 \\
\mathrm{H}_{9}: \text { CAAR }<0\end{array}$ & $t_{-1} 0.0217^{* * *}$ & 0.0076 \\
\hline \multirow[b]{2}{*}{ Governance } & positive & $\begin{array}{l}\mathrm{H}_{10}: \mathrm{AAR}>0 \mathrm{c} \\
\mathrm{H}_{11}: \mathrm{CAAR}>0\end{array}$ & $t_{-1} 0.0248^{* * *}$ & 0.0316 \\
\hline & negative & $\begin{array}{l}\mathrm{H}_{12}: \mathrm{AAR}<0 \mathrm{c} \\
\mathrm{H}_{13}: \mathrm{CAAR}<0\end{array}$ & $\begin{array}{l}t_{-1} 0.0038^{*} \\
t_{0}-0.0073^{*} \\
t_{1} 0.0045^{* *} \\
t_{2} 0.0079^{* * *}\end{array}$ & $0.0113 * *$ \\
\hline
\end{tabular}

c hypotheses confirmed; ${ }^{* * * *} 1 \%,{ }^{* * *} 5 \%,{ }^{* *} 10 \%, * 15 \%$ level of significance. Source: Own representation. 
These results confirm $\mathrm{H}_{2}$ that the announcement of a positive CSR-relevant news with environmental context leads to significant positive average abnormal returns in the time window investigated. Also, the results confirm $\mathrm{H}_{3}$ that these conditions lead to a significant positive cumulated average abnormal return. Therefore, the null hypothesis is rejected in each case.

\subsubsection{Environment-Negative}

A total of six announcements were assigned to this category. Positive average abnormal returns were observed in the period of two days prior to reporting until one day later. This was determined in a negative form two days after the event. The only significant average abnormal return was detected on the day of the announcement as a positive value (Table 9). The cumulated average abnormal return was not significant, as shown in Table 9.

These results do not confirm $\mathrm{H}_{4}$-that the announcement of negative CSR-relevant news with environmental context leads to significant negative average abnormal returns in the time window investigated. Additionally, the results do not confirm $\mathrm{H}_{5}$ that these conditions lead to a significant negative cumulated average abnormal return. Therefore, the null hypothesis cannot be rejected in each case.

\subsubsection{Society-Positive}

Forty-four messages have been assigned to this category. Positive average abnormal returns were observed on all five days of the time window studied, with significance being detected only two days before and on the day after the event (Table 9). The result of the cumulated average abnormal return has a significant positive value.

These results confirm $\mathrm{H}_{6}$ that the announcement of positive CSR-relevant news with societal context leads to significant positive average abnormal returns in the time window investigated. Also, the results confirm $\mathrm{H}_{7}$ that these conditions lead to a significant positive cumulated average abnormal return. Therefore, the null hypothesis is rejected in each case.

\subsubsection{Society-Negative}

Six announcements have been assigned to this section. Events from this category resulted in negative average abnormal returns on four days, two days before, on the day of the event and on the two following days. The only positive value and the only significant one was shown on the day before the announcement. Table 9 shows that a cumulated average abnormal return in the positive range was found in the time window, which has no significance.

These results do not confirm $\mathrm{H}_{8}$ that the announcement of negative CSR-relevant news with societal context leads to significant negative average abnormal returns in the time window investigated. Also, the results do not confirm $\mathrm{H}_{9}$ that these conditions lead to a significant negative cumulated average abnormal return. Therefore, the null hypotheses cannot be rejected in each case.

\subsubsection{Governance-Positive}

A total of eight announcements have been assigned to this section. The average abnormal returns were positive on the two days before and the two days after the report. The only negative average abnormal return was detected on the day of the report. The only significant observation was positive on the day before the event. The cumulated average abnormal return is positive, but the value is not statistically significant from zero as shown in Table 9.

These results confirm $\mathrm{H}_{10}$ that the announcement of positive CSR-relevant news with governance context leads to significant positive average abnormal returns in the time window investigated. The results do not confirm $\mathrm{H}_{11}$ that these conditions lead to a significant positive cumulated average abnormal return. Therefore, the null hypothesis is rejected for $\mathrm{H}_{10}$, but not for $\mathrm{H}_{11}$. 


\subsubsection{Governance-Negative}

Thirty-two announcements in this category led to an observation of a significant average abnormal return on four out of five days (Table 9). On the day before the event and the two following days, the values were positive. The only negative value was observed on the day of the announcement. The result of the cumulated average abnormal return is a positive and a significant value (Table 9).

These results confirm $\mathrm{H}_{12}$ that the announcement of negative CSR-relevant news with governance context leads to significant negative average abnormal returns in the time window investigated. These results do not confirm $\mathrm{H}_{13}$ that these conditions lead to a significant negative cumulated average abnormal return. Therefore, the null hypothesis is rejected for $\mathrm{H}_{12}$, but not for $\mathrm{H}_{13}$.

Based on the significant empirical results presented so far, it can be concluded that the null hypothesis $\mathrm{H}_{0}$ can be rejected and $\mathrm{H}_{1}$ can, thus, be assumed.

\subsection{Robustness Check}

To test the robustness of our event study, we performed the same study with a change in the observed trading days prior to the window we examined. We have changed the number from 252 to 126 or 63 days, with the expected return not based on the last year, but on the last six months or three months before the event, respectively. The results of this robustness test confirm the trends and conclusions of the original event study. The results of the robustness test for 126 days are shown in Table A4 in Appendix A. The results for 63 days show the same pattern and are therefore not presented separately.

In accordance with the described methodology, we used the market model to estimate abnormal returns. This is the most common model used in event studies where more advanced models do not necessarily improve the goodness of fit (Becchetti et al. 2012; Cable and Holland 1999). The distribution of $R^{2}$ is shown in Figure 2. The goodness of fit of the regression is within the usual limits and appropriate for the purpose.

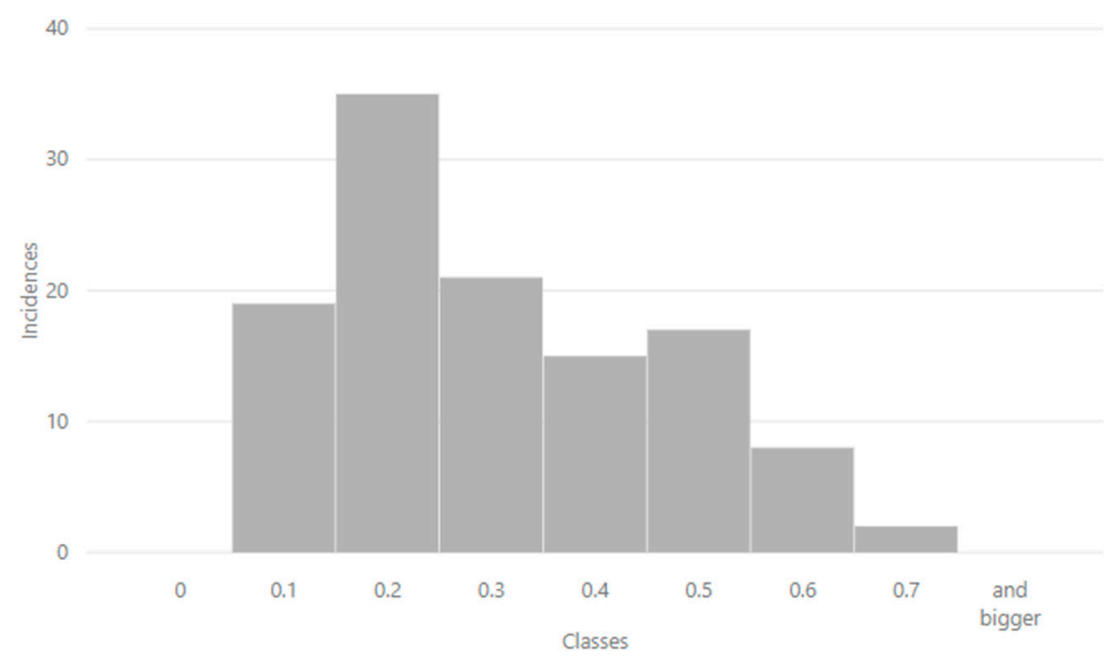

Figure 2. Distribution of $R^{2}$. Source: Own representation.

\section{Discussion of the Results}

\subsection{Summary}

The average abnormal returns examining the possible effects of CSR-related news on stock prices in the time window confirm the theory only partly. Out of a total of 30 days studied, eleven had statistically significant results. Out of these eleven significant abnormal returns, ten were positive and only one negative. The trend expected out of the theory was confirmed in only six cases but refuted in five. 
A positive cumulated average abnormal return was found in all six categories studied, whereas only three were significant. These were observed in the sections Environment-Positive, Society-Positive, and Governance-Negative. The theory expects a positive result for positive reports, and vice versa. While the results in the first two significant results confirm the expectations from the literature, the third result mentioned had a development in the opposite direction, like the theoretically expected negative result. Empirical evidence did not confirm this expectation of negative cumulated average returns in a single case.

Based on these results, it is reasonable to state that any company announcement in the CSR area trigger a positive effect in the form of cumulated average abnormal returns and that negative effects can only be observed within the short-term period of a day. On the one hand, these results partially confirm the expectations of the theory while, on the other hand, they refute them. The research suggests that the positive cumulated average abnormal returns are less related to content, but more to the company's short-term media presence.

\subsection{Critical Acclaim}

Event studies examine only short-term effects of published information on stock prices (Chan et al. 2000). An assessment of long-term development due to individual management actions is not optimally reflected (McWilliams et al. 1999; Jeng 2015). With a sample size of 129 this study is below the optimal size of 170-200 taken from the ten studies compared in the literature review. An extension of the research from 3 to 5 to 10 years will, therefore, have a positive effect on the result's relevance (Chan et al. 2000; Zhang 2014). Although the selection and classification of the CSR-relevant events examined was as objective as possible and carried out according to fixed criteria, the subjectivity it contains leaves a possible bias.

The current empirical research is mainly based on the results of the $t$-tests. This is the first step of the analysis to examine the impact of CSR news. The next step is to conduct a regression analysis with CAR, AAR and CAAR as dependent variables to measure the effects of other factors that could have an influence on the return.

In addition, only news from the platform finanzen.net was analyzed for the composition of the sample. Although the market leader serves as a source, a possible error rate remains to be accepted in terms of completeness (Schmidt 1982; Jennings and Starks 1985). Another point of criticism is the danger that a market does not optimally assess the observed event and thus over- or underestimates the corresponding announcement (Klassen and McLaughlin 1996). In this respect, a comparison with other markets is helpful as there is a different level of market efficiency and liquidity that could impact the results (Jennings and Starks 1985; Chan et al. 2000). In the future, it will be necessary to further investigate to what extent the proven effects can be attributed to the topic of CSR and not merely to the naming of the company in the media (Mumford 2016). The corresponding follow-up study would aim to find statistical evidence that assign the elements of the reactions to each of the two possible factors.

\subsection{Implications}

The result of the study is that positive CSR-relevant news in the areas of environment and society have a significant positive impact on stock prices in the short-term. From these results, the recommendation can be derived for companies to integrate CSR in order to obtain an additional tool for the company's management to influence the stock price in short-term for a specific cause. For companies, this study proves that the integration of CSR not only opens up numerous opportunities in the fields of economic, environmental and social affairs but that CSR can also be used as an element for controlling the stock price (Barth and Wolff 2009). Furthermore, the research findings have identified a way to measure the success of CSR and thereby increased the monetary incentive for the integration of CSR (Brejning 2016).

Now that the companies listed in the ATX have been provided with additional tools and space for actions, it is up to the organizations to implement these tools in practice and to unlock new 
potentials. In theory, the possibilities of applying stock price control lie in the aimed increase of the market value of the company, the associated marketing for the target group of the investors and improvement of the company's seal of quality (Lechler 2003). In addition, the aimed increase in the stock price provides possible protection against external takeovers and the possibilities of action of the company's management is widened by reducing the involvement of the shareholders in the business (Schäfer 1999; Lechler 2003). Opportunities are being created to prepare the stock price specifically for the implementation of capital measures and, thus, to optimize its overall process (Hermanns 2006).

As a result, it is possible to derive the exact recommendation for companies to integrate CSR into the company and, subsequently, to regularly publish CSR-relevant news via the platform finanzen.net in order to obtain a short-term improvement of the individual stock price and, therefore, to benefit from the added opportunities.

\section{Conclusions}

The event study concluded that both positive and negative CSR-related events over the last three years had a positive overall effect on ATX stocks in the form of accumulated average abnormal returns. However, only half of the cumulated average abnormal returns were significant. These were the positive reports related to the environmental category, the positive ones related to the category society and the negative ones to the category governance. Thus, although the impact of CSR-related reports on stock prices was confirmed, a negative cumulated average abnormal return was never observed. Therefore, the expected trend, whether positive or negative, has not been shown to play a decisive role. The event study conducted confirms the hypothesis that CSR-relevant reports lead to abnormal returns in the time window studied.

The tendency expected from the other hypotheses, positive or negative, was only confirmed in selected cases. Ten out of eleven significant abnormal returns in the event window were positive, only one was negative. Thus, the theory of a clearly visible tendency in both directions is only partially confirmed. The results of the research can, thus, be interpreted as meaning that CSR-relevant news leads to changes in stock prices, although these are only partially due to the content. Presumably, the media presence initiated with the announcement is an influential factor. In order to verify this statement, a follow-up study is necessary.

For companies, these research results are important as it shows that CSR-relevant events can be used to influence the stock price according to individual needs. These include a wanted increase in the market value of the company, marketing for investors or strengthening the individual brand. Based on the research findings demonstrating a positive effect of CSR-related news, an increase in the relevance of CSR in companies is to be expected, as the shareholder value is profiting from that. Thus, the integration of CSR not only creates measurable added value for the shareholder but also for the environment and society.

Author Contributions: Conceptualization, F.B. and M.E.; methodology, F.B.; validation, F.B. and M.E.; formal analysis, F.B.; resources, F.B. and M.E.; data curation, F.B.; writing—original draft preparation, F.B.; writing-review and editing, M.E.; visualization, F.B.; supervision, M.E.; project administration, M.E.

Funding: This research received no external funding.

Acknowledgments: We thank for the administrative and technical support of Eva-Maria Eder.

Conflicts of Interest: The authors declare no conflict of interest. 


\section{Appendix A}

Table A1. Days when the ATX was not published.

\begin{tabular}{ccl}
\hline & Date & \multicolumn{1}{c}{ Reason } \\
\hline 1 & 31 May 2018 & Corpus Christi \\
2 & 21 May 2018 & Whit Monday \\
3 & 10 May 2018 & Ascension of Christ \\
4 & 8 December 2017 & Mary's conception \\
5 & 1 November 2017 & All Saints' Day \\
6 & 26 October 2017 & National holiday \\
7 & 15 June 2017 & Corpus Christi \\
8 & 25 May 2017 & Ascension of Christ \\
9 & 2 January 2017 & No data on finance.yahoo.com \\
10 & 16 January 2015 & No data on finance.yahoo.com \\
11 & 24 December 2014 & Christmas eve \\
\hline
\end{tabular}

Source: Own representation based on Yahoo Finance.

Table A2. CSR-relevant notifications on non-trading days.

\begin{tabular}{cclc}
\hline & $\boldsymbol{t}_{\mathbf{0}}$ Report & \multicolumn{1}{c}{ Reason } & $\boldsymbol{t}_{\mathbf{0}}$ Used \\
\hline 1 & 14 July 2018 & Sunday & 16 July 2018 \\
2 & 9 April 2018 & No data on finance.yahoo.com & 10 April 2018 \\
3 & 11 February 2018 & Sunday & 12 February 2018 \\
4 & 19 August 2017 & Saturday & 21 August 2017 \\
5 & 25 May 2017 & Ascension of Christ & 26 May 2017 \\
\hline \multicolumn{4}{c}{ Source: own representation based on Yahoo Finance. }
\end{tabular}

Table A3. CSR-relevant messages between 17:31h and 23:59h.

\begin{tabular}{cccc}
\hline & $\boldsymbol{t}_{\mathbf{0}}$ Report & Time of Announcement & $\boldsymbol{t}_{\mathbf{0}}$ Used \\
\hline 1 & 20 April 2018 & 19:07 h & 23 April 2018 \\
2 & 9 October 2017 & $17: 51 \mathrm{~h}$ & 10 October 2017 \\
3 & 12 September 2017 & $18: 52 \mathrm{~h}$ & 13 September 2017 \\
4 & 19 April 2017 & $18: 13 \mathrm{~h}$ & 20 April 2017 \\
5 & 19 January 2016 & $23: 13 \mathrm{~h}$ & 20 January 2016 \\
6 & 26 November 2015 & 18:01 h & 27 January 2015 \\
\hline
\end{tabular}

Source: own representation based on Yahoo Finance.

Table A4. Results of robustness check (126 days).

\begin{tabular}{|c|c|c|c|c|}
\hline Category & Tendency of Reports & Hypotheses Established & AAR & CAAR \\
\hline \multirow[t]{2}{*}{ Environment } & positive & $\begin{array}{l}\mathrm{H}_{2}: \mathrm{AAR}>0 \mathrm{c} \\
\mathrm{H}_{3}: \mathrm{CAAR}>0 \mathrm{c}\end{array}$ & $\begin{array}{l}t_{-1} 0.0048^{*} \\
t_{1} 0.0112 * * * *\end{array}$ & $0.0101 * *$ \\
\hline & negative & $\begin{array}{l}\mathrm{H}_{4}: \mathrm{AAR}<0 \\
\mathrm{H}_{5}: \mathrm{CAAR}<0\end{array}$ & $t_{0} 0.0127^{* * *}$ & 0.0171 \\
\hline \multirow[t]{2}{*}{ Society } & positive & $\begin{array}{l}\mathrm{H}_{6}: \text { AAR }>0 \mathrm{c} \\
\mathrm{H}_{7}: \mathrm{CAAR}>0 \mathrm{c}\end{array}$ & $\begin{array}{l}t_{-2} 0.0057^{* * *} \\
t_{1} 0.0064^{* * *}\end{array}$ & $0.0150^{* * *}$ \\
\hline & negative & $\begin{array}{l}\mathrm{H}_{8}: \mathrm{AAR}<0 \\
\mathrm{H}_{9}: \mathrm{CAAR}<0\end{array}$ & $t_{-1} 0.0250 * * *$ & 0.0093 \\
\hline \multirow[t]{2}{*}{ Governance } & positive & $\begin{array}{l}\mathrm{H}_{10}: \mathrm{AAR}>0 \mathrm{c} \\
\mathrm{H}_{11}: \mathrm{CAAR}>0\end{array}$ & $t_{-1} 0.0259^{* * *}$ & 0.0351 \\
\hline & negative & $\begin{array}{l}\mathrm{H}_{12}: \mathrm{AAR}<0 \mathrm{c} \\
\mathrm{H}_{13}: \mathrm{CAAR}<0\end{array}$ & $\begin{array}{l}t_{0}-0.0075^{*} \\
t_{1} 0.0045^{* *} \\
t_{2} 0.0078^{* * *}\end{array}$ & $0.0105^{* *}$ \\
\hline
\end{tabular}

c hypotheses confirmed; ${ }^{* * * *} 1 \%,{ }^{* * *} 5 \%,{ }^{* *} 10 \%, * 15 \%$ level of significance. Source: own representation. 


\section{References}

Arya, Bindu, and Gaiyan Zhang. 2009. Institutional Reforms and Investor Reactions to CSR Announcements. Evidence from an Emerging Economy. Journal of Management Studies 46: 1089-112. [CrossRef]

Babiak, Kathy, and Sylvia Trendafilova. 2011. CSR and Environmental Responsibility. Motives and Pressures to Adopt Green Management Practices. Corporate Social Responsibility and Environmental Management 18: 11-24. [CrossRef]

Barth, Regine, and Franziska Wolff. 2009. Corporate Social Responsibility and sustainability impact: Opening up the arena. In Corporate Social Responsibility in Europe. Rhetoric and Realities. Edited by Regine Barth and Franziska Wolff. Cheltenham: Edward Elgar, pp. 3-25.

Becchetti, Leonardo, Rocco Ciciretti, Iftekhar Hasan, and Nada Kobeissi. 2012. Corporate Social Responsibility and Shareholder's Value. Journal of Business Research 65: 1628-35. [CrossRef]

Borowy, Iris. 2014. Defining Sustainable Development for Our Common Future. A History of the World Commission on Environment and Development (Brundtland Commission). London: Routledge.

Bowman, Robert. 1983. Understanding and Conducting Event Studies. Journal of Business Finance E Accounting 10: $561-84$.

Brejning, Jeanette. 2016. Corporate Social Responsibility and the Welfare State. The Historical and Contemporary Role of CSR in the Mixed Economy of Welfare. London: Routledge.

Cable, John, and Kevin Michael Holland. 1999. Modelling normal returns in event studies: A model-selection approach and pilot study. The European Journal of Finance 5: 331-41. [CrossRef]

Capelle-Blancard, Gunther, and Aurélien Petit. 2017. Every little helps? ESG news and stock market reaction. Journal of Business Ethics 157: 543-65. [CrossRef]

Cellier, Alexis, and Pierre Chollet. 2011. The Impact of Corporate Social Responsibility Rating Announcement on Stock Prices: An Event Study on European Markets. Paper presented at International Conference of the French Finance Association (AFFI), Montpellier, France, May 11-13; pp. 1-33.

Chan, Kalok, Allaudeen Hameed, and Wilson Tong. 2000. Profitability of momentum strategies in the international equity markets. Journal of Financial and Quantitative Analysis 2: 153-72. [CrossRef]

Cheung, Adrian. 2010. Do Stock Investors Value Corporate Sustainability? Evidence from an Event Study. Journal of Business Ethics 2: 145-65.

Dhaliwal, Dan, Oliver Zhen Li, Albert Tsang, and Yong Georg Yang. 2014. Corporate social responsibility disclosure and the cost of equity capital: The roles of stakeholder orientation and financial transparency. Journal of Accounting and Public Policy 33: 328-55. [CrossRef]

Fama, Eugene Francis. 1991. Efficient Capital Markets: II. The Journal of Finance 46: 1575-617. [CrossRef]

Freeman, Robert Edward. 1984. Strategic Management: A Stakeholder Approach. Boston: Pitman.

Godfrey, Paul, Craig Merril, and Jared Hansen. 2009. The relationship between corporate social responsibility and shareholder value. An empirical test of the risk management hypothesis. Strategic Management Journal 30: 425-45. [CrossRef]

Griffin, Paul, and Yuan Sun. 2013. Going green. Market reaction to CSR newswire releases. Journal of Accounting and Public Policy 32: 93-113. [CrossRef]

Hamilton, James. 1995. Pollution as News. Media and Stock Market Reactions to the Toxics Release Inventory Data. Journal of Environmental Economics and Management 28: 98-113. [CrossRef]

Hannon, John, and George Milkovich. 1996. The Effect of Human Resource Reputation Signals on Share Prices. An Event Study. Human Resource Management 3: 405-24. [CrossRef]

Harjoto, Maretno Agus, and Hoje Jo. 2015. Legal vs. normative CSR: Differential impact on analyst dispersion, stock return volatility, cost of capital, and firm value. Journal of Business Ethics 128: 1-20. [CrossRef]

Hermanns, Julia. 2006. Optimale Kapitalstruktur und Market Timing. Empirische Analyse Börsennotierter Deutscher Unternehmen. Wiesbaden: GWV.

ISO. 2010. ISO 26000. Guidance on Social Responsibility. Geneva: ISO.

Jeng, Jau-Lian. 2015. Analyzing Event Statistics in Corporate Finance. Methodologies, Evidences, and Critiques. New York: Palgrave Macmillan.

Jennings, Robert, and Laura Starks. 1985. Information content and the speed of stock price adjustment. Journal of Accounting Research 1: 336-50. [CrossRef] 
Jones, Oliver, and Rachel Louise Gomes. 2014. Chemical Pollution of the Aquatic Environment by Priority Pollutants and its Control. In Pollution. Causes, Effects and Control. Edited by R. Harrison. Cambridge: The Royal Society of Chemistry, pp. 1-31.

Jonker, Jan, Wolfgang Stark, and Stefan Tewes. 2011. Corporate Social Responsibility und Nachhaltige Entwicklung. Einführung, Strategie und Glossar. Berlin/Heidelberg: Springer.

Karpoff, Jonathan, John Lott, and Eric Wehrly. 2005. The reputational penalties for environmental violations. Empirical evidence. Journal of Law and Economics 48: 653-75. [CrossRef]

Keinert-Kisin, Christina. 2015. CSR in Austria: Exemplary Social and Environmental Practice or Compliance-Driven Corporate Responsibility? Corporate Social Responsibility in Europe, 137-51. [CrossRef]

Klassen, Robert, and Curtis McLaughlin. 1996. The Impact of Environmental Management on Firm Performance. Management Science 8: 1199-214. [CrossRef]

Kliger, Doron, and Gregory Gurevich. 2014. Event Studies for Financial Research. A Comprehensive Guide. New York: Palgrave Macmillan.

Kothari, S. P., and Jerold Warner. 2008. Econometrics of Event Studies. In Handbook of Corporate Finance. Empirical Corporate Finance. Edited by B. Espen Eckbo. Amsterdam: North Holland, Elsevier, vol. 1, pp. 3-36.

Krüger, Philipp. 2015. Corporate Goodness and Shareholder Wealth. Journal of Financial Economics 115: 304-29. [CrossRef]

Lechler, Jörg. 2003. Investor Marketing aus Sicht eines Emissionshauses. In Investor Marketing. Aktionäre erfolgreich gewinnen. Investoren langfristig binden. Börsenkurse nachhaltig steigern. Edited by Bernhard Ebel and Markus Hofer. Wiesbaden: Gabler, pp. 79-94.

Lee, Jooh, and James Jungbae Roh. 2012. Revisiting corporate reputation and firm performance link. Benchmarking. An International Journal 4: 649-64. [CrossRef]

Mayring, Philipp. 2016. Einführung in die qualitative Sozialforschung. Eine Anleitung zu qualitativem Denken. Weinheim: Beltz.

McWilliams, Abagail, Donald Siegel, and Siew Hong Teoh. 1999. Issues in the Use of the Event Study Methodology. A Critical Analysis of Corporate Social Responsibility Studies. Organizational Research Methods 2: 340-65. [CrossRef]

Mitchell, Mark, and Jeffry Netter. 1994. The Role of Financial Economics in Securities Fraud Cases. Applications at the Securities and Exchange Commission. The Business Lawyer 2: 545-90.

Morris, Gregory. 2014. Investing with the Trend. A Rules-based Approach to Money Management. Hoboken: John Wiley \& Sons.

MSCI ESG Research. 2015. MSCI ESG Rating Methodology. Executive Summary. New York: MSCI Inc.

MSCI Inc. 2018. MSCI KLD 400 Social Index (USD). Available online: https://www.msci.com/documents/10199/ 904492e6-527e-4d64-9904-c710bf1533c6 (accessed on 6 February 2019).

Mumford, Paul. 2016. The Stock Picker. A Financial History from the Sharp End. Petersfield: Harriman House.

Oikonomou, Ioannis, Aspasia Pastra, and Ilias Visvikis. 2018. A Financial Business Case for Corporate Social Responsibility. In Corporate Social Responsibility in the Maritime Industry. Edited by Lisa Loloma Froholdt. Cham: Springer, pp. 219-36.

Ramchander, Sanjay, Robert Schwebach, and KIM Staking. 2012. The Informational Relevance of Corporate Social Responsibility. Evidence from DS400 Index Reconstitutions. Strategic Management Journal 33: 303-14. [CrossRef]

Schäfer, Frank. 1999. Zulässigkeiten und Grenzen der Kurspflege. WM, 1345-52.

Schiff, Felix, and Stéphanie Mittelbach-Hörmanseder. 2018. Verpflichtende Nachhaltigkeitsberichterstattung. Ein Überblick. RWZ 1: 34-7.

Schmidt, Reinhard. 1982. Rechnungslegung als Informationsproduktion auf nahezu effizienten Kapitalmärkten. Schmalenbach Zeitschrift für betriebswirtschaftliche Forschung 34: 728-48.

Schnell, Rainer, Paul Hill, and Elke Esser. 2013. Methoden der Empirischen Sozialforschung. Munich: Oldenbourg.

Smith, Michael, Karlson James Hargroves, and Cheryl Julia Kiran Desha. 2010. Cents and Sustainability. Securing Our Common Future by Decoupling Economic Growth from Environmental Pressures. London: Routledge.

Vilain, Michael. 2010. Meine Firma, meine Mitarbeiter, meine Heimat. Merkmale unternehmerischen Engagement im deutschen Mittelstand. In Gesellschaftliches Engagement von Unternehmen. Der deutsche Weg im internationalen Kontext. Edited by Sebastian Braun. Wiesbaden: Vs, pp. 106-39. 
White, Gwendolen. 2009. Sustainability Reporting. Managing for Wealth and Corporate Health. New York: Business Expert Press.

Wiener Börse. 2018. Zusammensetzung ATX. Available online: https://www.wienerborse.at/indizes/aktuelleindexwertezusammensetzung/?ID_NOTATION=92866\&ISIN=AT0000999982 (accessed on 31 August 2018).

Wiener Börse. 2019a. Definition ATX. Available online: https://www.wienerborse.at/wissen/boersenlexikon/ buchstabe-a/atx/ (accessed on 7 February 2019).

Wiener Börse. 2019b. Österreichs größter Börsengang: BAWAG Group AG im PRIME market der Wiener Börse gelistet. Available online: https://www.wienerborse.at/news/wiener-boerse-news/news/borsengang-bawaggroup/ (accessed on 7 February 2019).

Zhang, Ying. 2014. Stock Message Boards. A Quantitative Approach to Measuring Investor Sentiment. New York: Palgrave Macmillan.

(C) 2019 by the authors. Licensee MDPI, Basel, Switzerland. This article is an open access article distributed under the terms and conditions of the Creative Commons Attribution (CC BY) license (http://creativecommons.org/licenses/by/4.0/). 